\title{
Effect of methionine supplementation on the growth performance of rabbit
}

\author{
S Yesmin ${ }^{1}$, ME Uddin ${ }^{2}$, R Chacrabati ${ }^{1}$, M Al-Mamun* ${ }^{1}$ \\ ${ }^{1}$ Department of Animal Nutrition, ${ }^{2}$ Department of Dairy Science, Bangladesh Agricultural University, \\ Mymensingh 2202, Bangladesh
}

\begin{abstract}
The present study was conducted to evaluate the effect of different levels of methionine supplementation on feed intake, nutrient digestibility and growth performance of growing rabbit. Sixteen weaned crossbred New Zealand White (NZW) growing rabbits (30-35 d) were distributed into four treatment groups having four replications in each group using a Completely Randomized Design (CRD). Basal diet composed of green grass (dhal grass) and concentrate mixture which was offered ad libitum basis for 56 days period. Four levels of methionine such as $0.0 \%$ (control), $0.15 \%, 0.25 \%$, and $0.35 \%$ were supplemented randomly to rabbits. Results showed that supplementation of methionine did not affect green grass intake. Cumulative as well as daily concentrate and DM intake were significantly $(p<0.05)$ higher for all methionine groups than control group. Final body weight gain as well as daily, weekly and cumulative body weight gains were improved significantly with increasing level of methionine. It was found that methionine had significant $(p<0.01)$ effect on digestibility of DM, CP, NFE and EE but CF digestibility did not differ significantly. Digestibility was improved with increasing the level of methionine. Feed conversion ratio also decreased significantly with methionine supplementation, and $0.25 \%$ methionine group showed the best performance among the four treatments.
\end{abstract}

Key words: Digestibility, growth, rabbit, methionine, supplementation

Bangladesh Animal Husbandry Association. All rights reserved.

Bang. J. Anim. Sci. 2013. 42 (1): 40-43

\section{I ntroduction}

Rabbits grow rapidly and their growth rate is comparable to that of broiler chicken. Rabbit's meat is acknowledged as of high quality meat being high in protein but low in fat and cholesterol and sodium (J ones, 1990). Rabbits are efficient converters of feed to meat and can utilize up to $30 \%$ crude fibre as against $10 \%$ by most poultry species (Egbo et al. 2001). Domestic rabbit (Oryctolagus cuniculus) is emerging as a viable livestock species which is suited to smallscale production by backyard farming (Cheeke 1989). Rabbits grow rapidly and their growth rate is comparable to that of broiler chicken (Rao et al. 1977). Rabbit as a micro-livestock (Vietmeyer 1985) may be a promising enterprise in this respect. For many years enteritis has been a principal cause of mortality among young domestic rabbits (Lund 1951). Since the gross appearance of rabbits with enteritis suggests a toxic condition, and amino acids are known to be involved in detoxification, it was felt that amino acid supplementation might be effective in reducing the incidence of this condition. Lysine and methionine had showed that they have effects on growth and protein utilization in other.
Yono et al. (1986) reported that methionine is an important essential amino acid for reproductive performance of rabbits. An experiment of methionine supplementation on growing rabbit was also conducted by Hossain (2003) and he used only one dose of methionine and found nonsignificantly higher growth of supplemented group and suggested to find out the appropriate level of methionine supplementation for growing rabbit. So, the present study was conducted to evaluate the different levels of methionine supplementation with concentrate mixture on feed intake, nutrient digestibility and growth performance of rabbit.

\section{Materials and Methods}

The experiment was carried out at the Shahjalal Animal Nutrition Field Laboratory, Bangladesh Agricultural University, Mymensingh for a period of 56 days. All of the experimental animals were housed individually in all steel, Quonset style cages (Harris, 1983), measuring $1.95 \mathrm{~m} \times 1.80 \mathrm{~m} \times$ $1.27 \mathrm{~m}$ in dimension. A J-shaped screened metal feeder and $250 \mathrm{ml}$ bottle waterer with steel straw were provided in each cage. 


\section{Experimental design}

Fifteen weaned crossbred New Zealand White (NZW) growing rabbits aged about 30-35 days and the average initial live weight of the rabbits ranging from 285 to $295 \mathrm{gm}$, were randomly assigned to four dietary treatment in a Completely Randomized Design (CRD) each having four replications. The dietary treatments were: $\mathrm{T}_{0}=$ Green grass + (Concentrate mixture containing $0.0 \%$ methionine); $\mathrm{T}_{1}=$ Green grass + (Concentrate mixture containing $0.15 \%$ methionine); $\mathrm{T}_{2}=$ Green grass + (Concentrate mixture containing $0.25 \%$ methionine); $\mathrm{T}_{3}=$ Green grass + (Concentrate mixture containing $0.35 \%$ methionine).

Concentrate mixture and green grass was offered ad libitum basis twice daily, once in the morning at $8.00 \mathrm{am}$ and another in the afternoon at 4.00 pm. Pure drinking water was also available at all times. The rabbits were weighed individually at the beginning of the experiment and thereafter the rabbits were weighed individually in every week by using a weighing balance before morning feeding. Towards the end of the feeding trial, a conventional digestibility trial was conducted for a period of 7 days. Samples of feeds, feces and green grass were analyzed for moisture, crude protein $(C P)$, crude fiber (CF), ether extract (EE), ash and nitrogen free extract (NFE) following the methods of AOAC (2004). Feed consumption ( $\mathrm{g} /$ rabbit), feed conversion ratio (FCR) and average daily gain (ADG) were also calculated.

Table 1. Nutrient composition (g/100g) of experimental diets (concentrate mixture + green grass)

\begin{tabular}{|c|c|c|c|c|}
\hline \multirow{2}{*}{$\begin{array}{l}\text { Nutrients } \\
(\mathrm{g} / 100 \mathrm{~g})\end{array}$} & \multicolumn{4}{|c|}{ Dietary Treatment (\% Methionine) } \\
\hline & $\begin{array}{c}T_{0} \\
(0.0)\end{array}$ & $\begin{array}{c}T_{1} \\
(0.15)\end{array}$ & $\begin{array}{c}T_{2} \\
(0.25)\end{array}$ & $\begin{array}{c}T_{3} \\
(0.35)\end{array}$ \\
\hline$\overline{\mathrm{DM}}$ & 88.86 & 88.72 & 88.67 & 88.54 \\
\hline $\mathrm{CP}$ & 16.41 & 16.39 & 16.38 & 16.35 \\
\hline $\mathrm{CF}$ & 4.37 & 4.37 & 4.36 & 4.35 \\
\hline EE & 5.03 & 5.03 & 5.02 & 5.00 \\
\hline NFE & 55.45 & 55.37 & 55.39 & 55.34 \\
\hline Ash & 7.60 & 7.56 & 7.52 & 7.50 \\
\hline$* \mathrm{Ca}$ & 0.46 & 0.45 & 0.45 & 0.44 \\
\hline$* p$ & 0.33 & 0.33 & 0.32 & 0.32 \\
\hline Methionine & $0.24 *$ & 0.39 & 0.49 & 0.59 \\
\hline $\begin{array}{l}\text { *ME (Kcal/ } \\
\text { kg DM) }\end{array}$ & 2726.00 & 2721.00 & 2718.24 & 2715.18 \\
\hline
\end{tabular}

The data were analyzed using the "MSTAT" statistical program to compute analysis of variance (ANOVA) for a Completely Randomized Design (CRD). Duncan's Multiple Range Test (DMRT) was also done for different parameter to compare the treatment means for different parameter (Steel and Torrie, 1980).

\section{Results and Discussion}

\section{Dry Matter (DM) intake}

Cumulative as well as daily DM intake was shown higher values with increasing the level of methionine in the diet. Methionine supplementation increased DM intake of rabbit which is found by Parigi et al. (1988).

\section{Growth performance}

The results indicated that supplementation of methionine had effect on final body weight, daily, weekly and cumulative body weight gain. This result agrees with Al-Homidan (2001) who reported that daily live weight gain increased significantly with supplementation of methionine $(0.2 \%)$ in the diet. Zhang and Li (2010) showed that $0.2 \%, 0.4 \%$ and $0.6 \%$ methionine in the diet resulted higher average daily gain than that of $0 \%$ methionine diet group $(p<0.01)$.

\section{Nutrient digestibility}

Digestibility of nutrients was improved significantly with increasing the level of methionine. As digestibility is influenced by many factors, so the actual reason of improvement of digestibility is not clear to us yet. Further study is necessary specifically on digestibility of rabbit as affected by supplementation of methionine.

\section{Feed conversion ratio}

The effect of methionine supplementation on FCR of growing rabbit was significant $(p<0.01)$ (Table 4). This result is supported by Sonbol et al. (1992) who reported that supplementation of methionine in diet increased feed conversion efficiency. Bhatt et al. (1997) also stated that methionine supplementation results in better feed conversion in growing rabbit. 
Table 2. Effect of methionine supplementation on total DM intake $(\mathrm{g}) \pm$ standard error of rabbit

\begin{tabular}{|c|c|c|c|c|c|}
\hline \multirow{2}{*}{$\begin{array}{c}\text { Age } \\
\text { (weeks) }\end{array}$} & \multicolumn{4}{|c|}{ Methionine level (\%) } & \multirow{2}{*}{ Sig. leve } \\
\hline & 0.0 & 0.15 & 0.25 & 0.35 & \\
\hline $1^{\mathrm{st}}$ & $251.71 \pm 10.75$ & $264.28 \pm 10.75$ & $286.34 \pm 10.75$ & $272.51 \pm 12.42$ & NS \\
\hline $2^{\text {nd }}$ & $286.61 \pm 7.70$ & $283.94 \pm 7.70$ & $310.73 \pm 7.70$ & $309.56 \pm 8.89$ & NS \\
\hline $3^{r d}$ & $428.73 \pm 9.41$ & $469.12 \pm 9.41$ & $456.99 \pm 9.41$ & $458.15 \pm 10.87$ & NS \\
\hline $4^{\text {th }}$ & $489.76 \pm 18.14$ & $498.23 \pm 18.14$ & $520.28 \pm 18.14$ & $521.87 \pm 20.95$ & NS \\
\hline $5^{\text {th }}$ & $476.49 \pm 20.81$ & $534.15 \pm 20.81$ & $520.02 \pm 20.81$ & $555.37 \pm 24.03$ & NS \\
\hline $6^{\text {th }}$ & $530.00 \pm 25.85$ & $566.21 \pm 25.85$ & $548.60 \pm 25.85$ & $559.26 \pm 29.85$ & NS \\
\hline $7^{\text {th }}$ & $551.26 \pm 18.63$ & $601.53 \pm 18.63$ & $583.64 \pm 18.63$ & $617.87 \pm 21.51$ & NS \\
\hline Cumulative & $3014.55 \pm 52.6^{b}$ & $3207.15 \pm 52.86^{a}$ & $3233.35 \pm 52.86^{a}$ & $3294.59 \pm 61.0^{a}$ & * \\
\hline Daily & $61.52 \pm 1.08^{\mathrm{b}}$ & $65.46 \pm 1.08^{\mathrm{a}}$ & $65.98 \pm 1.08^{a}$ & $67.23 \pm 1.25^{\mathrm{a}}$ & * \\
\hline
\end{tabular}

NS, non- significant $(p>0.05) ; *: 5 \%$ Level of significance $(p<0.05)$; ${ }^{\text {ab }}$ means values having different superscripts in the same row differ significantly

Table 3. Effect of methionine supplementation on mean body weight gain $(\mathrm{g}) \pm$ standard error

\begin{tabular}{|c|c|c|c|c|c|}
\hline \multirow[t]{2}{*}{ Week } & \multicolumn{4}{|c|}{ Methionine level (\%) } & \multirow{2}{*}{$\begin{array}{l}\text { Level } \\
\text { of sig. }\end{array}$} \\
\hline & 0.0 & 0.15 & 0.25 & 0.35 & \\
\hline Initial weight & $285.00 \pm 17.19$ & $290.00 \pm 17.19$ & $295.00 \pm 17.19$ & $290.00 \pm 19.85$ & NS \\
\hline Final weight & $900.50 \pm 35.18^{c}$ & $1055.00 \pm 35.18^{b}$ & $1207.50 \pm 35.18^{a}$ & $1131.00 \pm 40.62^{\mathrm{ab}}$ & $* *$ \\
\hline $1^{\mathrm{st}}$ & $77.25 \pm 5.77^{c}$ & $106.25 \pm 5.77^{b}$ & $126.25 \pm 5.77^{a}$ & $110.33 \pm 6.66^{\mathrm{ab}}$ & $* *$ \\
\hline $2^{\text {nd }}$ & $82.50 \pm 8.11^{\mathrm{b}}$ & $111.75 \pm 8.11^{\mathrm{a}}$ & $125.50 \pm 8.11^{\mathrm{a}}$ & $126.67 \pm 9.36^{\mathrm{a}}$ & $*$ \\
\hline $3^{\text {rd }}$ & $85.75 \pm 11.49$ & $102.50 \pm 11.4$ & $128.75 \pm 11.49$ & $120.00 \pm 13.27$ & NS \\
\hline $4^{\text {th }}$ & $80.00 \pm 10.70^{b}$ & $123.75 \pm 10.70^{a}$ & $128.75 \pm 10.70^{a}$ & $97.33 \pm 12.36^{\mathrm{ab}}$ & $*$ \\
\hline $5^{\text {th }}$ & $93.75 \pm 7.85^{c}$ & $117.50 \pm 7.85^{b c}$ & $143.75 \pm 7.85^{\mathrm{a}}$ & $135.00 \pm 9.07^{\mathrm{ab}}$ & $* *$ \\
\hline $6^{\text {th }}$ & $108.75 \pm 7.36^{\mathrm{a}}$ & $79.75 \pm 7.36^{b}$ & $123.25 \pm 7.36^{\mathrm{a}}$ & $128.33 \pm 8.50^{\mathrm{a}}$ & $* *$ \\
\hline $7^{\text {th }}$ & $87.50 \pm 10.44^{b}$ & $123.50 \pm 10.44^{\mathrm{a}}$ & $136.25 \pm 10.44^{a}$ & $123.33 \pm 12.06^{a}$ & $*$ \\
\hline Cumulative & $615.50 \pm 23.44^{c}$ & $765.00 \pm 23.44^{b}$ & $912.50 \pm 23.44^{a}$ & $841.00 \pm 27.07^{a}$ & $* *$ \\
\hline Daily & $12.56 \pm 0.48^{c}$ & $15.61 \pm 0.48^{b}$ & $18.62 \pm 0.48^{a}$ & $17.16 \pm 0.55^{\mathrm{a}}$ & $* *$ \\
\hline
\end{tabular}

NS, non- significant; $*, \mathrm{p}<0.05 ; * *, \mathrm{p}<0.01$; means with different superscripts in the same row differ significantly

Table 4. Effect of methionine supplementation on nutrient digestibility (\%) and FCR of rabbit

\begin{tabular}{|c|c|c|c|c|c|}
\hline \multirow[t]{2}{*}{ Nutrients } & \multicolumn{4}{|c|}{ Methionine level (\%) } & \multirow{2}{*}{$\begin{array}{l}\text { Level of } \\
\text { sig. }\end{array}$} \\
\hline & 0.0 & 0.15 & 0.25 & 0.35 & \\
\hline$\overline{D M}$ & $60.60 \pm 0.66^{b}$ & $64.28 \pm 0.66^{a}$ & $64.23 \pm 0.66^{a}$ & $62.87 \pm 0.76^{\mathrm{a}}$ & $* *$ \\
\hline $\mathrm{CP}$ & $58.48 \pm 0.43^{c}$ & $60.19 \pm 0.43^{b}$ & $62.05 \pm 0.43^{a}$ & $62.63 \pm 0.49^{a}$ & $* *$ \\
\hline $\mathrm{CF}$ & $43.85 \pm 0.44$ & $43.56 \pm 0.44$ & $44.75 \pm 0.44$ & $44.34 \pm 0.51$ & NS \\
\hline NFE & $66.17 \pm 0.59^{c}$ & $65.73 \pm 0.59^{c}$ & $68.03 \pm 0.59^{b}$ & $70.42 \pm 0.68^{a}$ & $* *$ \\
\hline EE & $46.46 \pm 0.49^{b}$ & $48.13 \pm 0.49^{a}$ & $45.20 \pm 0.49^{b}$ & $48.36 \pm 0.56^{a}$ & $* *$ \\
\hline FCR & $4.90 \pm 0.15^{\mathrm{a}}$ & $4.19 \pm 0.15^{b}$ & $3.54 \pm 0.15^{c}$ & $3.92 \pm 0.17^{b c}$ & $* *$ \\
\hline
\end{tabular}

NS, non- significant; $*, p<0.05 ; * *, p<0.01$; means with different superscripts in the same row differ significantly

\section{Conclusion}

Under present experimental condition, it may be concluded that $0.25 \%$ of supplementation of methionine in the diet of growing rabbit might be suggested for rabbit rearing.

\section{References}

Al-Homidan AH (2001). Growth performance and carcass traits of growing California rabbits as affected by methionine and/or lysine supplementation. The Egyptian Journal of Rabbit Science, 11:139-149.

AOAC (2004). Official Methods of Analysis (14th ed.). Association of official Analytical Chemists. Washington, DC, USA.

Bhatt RS, Bhasin V and Bhatia DR (1997). Effect of amino acid supplementation on performance of Soviet Chinchilla weaners fed mustard-cake-based diet. Indian journal of Animal Science, 67: 1101-1103.

Cheeke PR (1989). Production and nutrition of rabbits in tropical and subtropical 
agricultural systems. Nutrition Abstracts and Reviews (Series B), 61: 134.

Egbo ML, Doma UD and Lacdaks AB (2001). Characteristics of small scale rabbit production and management in Bauchi metropolis. Proceeding of the $26^{\text {th }}$ Annual Conference of Nigerian Society for Animal Production(NSAP). 18-21 March, ABU Zaria. 160-162

Harris DJ (1983). Construction of Quonset-style rabbit cages. Journal of Applied Rabbit Research, 6:142.

Hossain T (2003). Growth and reproductive performance of meat rabbit wth diet containing moderately high and low protein content with or without methionine. Master of Science Thesis, Department of Animal Nutrition, Bangladesh Agricultural University, Mymensingh.

Jones ND (1990). The developing market for farm-bred meat rabbits in Britain. Animal Production, 50: 66.

Lund EE (1951). Mortality among hutchraised domestic rabbits, circ. 883. Department of Agriculture. Washington, DC, USA.

NRC (National Research Council). (1977). Nutrient Requirements of Domestic Animals. No.9 Nutrient Requirements of Rabbits. 2nd Rev. edition. National Academy of Science, National Research Council, Washington, DC, USA.

Parigi BR, Xiccato $G$ and Cinetto M (1988). Methionine and lysine supplementation of complete diet for growing rabbits. Rivista-diConiglic, 25: 33-38.

Rao DR, Sunki GR, Johnston WM and Chen CP
(1977). Postnatal growth of New Zealand White Rabbit (Oryctolagus cuniculas). J ournal of Animal Science, 44: 1021.

Sonbol SM, Adb-Rahman GA, Sherif SA and Nasser MM (1992). Effect of inorganic sulphate supplements on the productive performance and some blood constituents of weaning New Zealand White Rabbits fed on sulfur amino acid deficient diets. The Egyptian Journal of Rabbit Science, 2: 8194.

Sonbol SM, EI-Bak SMA, El-gendy KM and Maria AM (1992). Effect of dietary protein level and sources on nutrient utilization and growth performance in New Zealand White rabbits. Nutrition Abstracts and Reviews, 64: 2058.

Steel RDG and Torrie JH (1980). A study of the need for fibre by growing New Zealand White rabbit. Journal of the Science of Food and Agriculture, 29: 640-648.

Vietmeyer ND (1985). Potentials of microlivestock in developing countries. Journal of Applied Rabbit Research, 4:16.

Yono CR, Cheeke PR and Patton NM (1986). Growth and reproductive performance of rabbits on moderately low crude protein diet with or without methionin or urea supplementation. Journal of Animal Science, 63: 795-803.

Zhang YC and Li FC (2010). Effect of dietary methionine on growth performance and insulin-like growth factor-I mRNA expression of growing meat rabbits. Journal of Animal Physiology and Animal Nutrition, 94: 803809. 